\title{
Activity of temocillin against ESBL-, AmpC-, and/or KPC-producing Enterobacterales isolated in Poland
}

\author{
Alicja Kuch $^{1}$ (D) - Bartłomiej Zieniuk ${ }^{1}$ (D) Dorota Żabicka ${ }^{1}$ (D) - Sebastien Van de Velde ${ }^{2}$ (D) Elżbieta Literacka ${ }^{1}$ (D) \\ Anna Skoczyńska ${ }^{1}$ (D) $\cdot$ Waleria Hryniewicz ${ }^{1}$ (I)
}

Received: 14 November 2019 / Accepted: 26 January 2020 / Published online: 24 February 2020

(C) The Author(s) 2020

\begin{abstract}
We evaluated the in vitro effectiveness of temocillin and several commonly used antimicrobials against Enterobacterales bacteria in isolates from Polish patients. We tested 400 isolates: 260 extended-spectrum $\beta$-lactamase (ESBL)- and/or ampC $\beta$-lactamase (AmpC)-producing isolates; 40 Klebsiella pneumoniae carbapenemase (KPC)-producing isolates; and $100 \mathrm{ESBL}-$, AmpC-, and KPC-negative isolates. The minimal inhibitory concentrations (MICs) of temocillin and 16 other antimicrobials were determined by reference microdilution. We also determined the activities of fosfomycin and ceftazidime/avibactam in KPC-producing isolates. The antibiotic sensitivities were interpreted according to EUCAST, BSAC, and CLSI criteria. Overall, 91\% of the isolates were susceptible to temocillin using the urinary tract infection breakpoint $(\leq 32 \mathrm{mg} / \mathrm{L})$, and $61.8 \%$ were susceptible using the systemic infection breakpoint $(\leq 8 \mathrm{mg} / \mathrm{L})$. Meropenem and imipenem were the most active drugs $\left(\mathrm{MIC}_{50}\right.$ values of 0.06 and $0.5 \mathrm{mg} / \mathrm{L}$, respectively). Colistin and ertapenem (both $\mathrm{MIC}_{50}=0.12 \mathrm{mg} / \mathrm{L}$ ) were less active than meropenem or imipenem, but some strains were $77 \%$ susceptible to each of them. Among the KPC-producing isolates, $42.5 \%$ had MIC values of $\leq 32 \mathrm{mg} / \mathrm{L}$ (urinary tract infection breakpoint), but 100\% were resistant to temocillin (systemic infection breakpoint). Ceftazidime/avibactam was active against $100 \%$ of the KPC-producing isolates, and fosfomycin was active against $40 \%$. The empirical susceptibility rate observed among the urinary isolates suggests that temocillin may be considered as an alternative to carbapenems in the absence of KPC-producing bacteria. With regard to isolates from other sources, temocillin might be useful as a documented therapy agent or an empirical treatment in hospitals with a low prevalence of ESBL/AmpC-producing strains.
\end{abstract}

Keywords Temocillin $\cdot$ Enterobacterales $\cdot \mathrm{ESBL} / \mathrm{AmpC} \cdot \mathrm{KPC}$

\section{Introduction}

Multidrug-resistant Enterobacterales bacteria have become a serious global concern, with limited therapeutic options for their control [1]. To meet the current challenges, there is an urgent need to discover new antimicrobials, or to re-examine known compounds such as fosfomycin, polymyxins, and temocillin [2].

Temocillin is a $\beta$-lactamase-resistant penicillin. It is the 6 - $\alpha$-methoxy derivative of ticarcillin, and is resilient to all

Dorota Żabicka

d.zabicka@nil.gov.pl

1 Department of Epidemiology and Clinical Microbiology, National Medicines Institute, Chełmska 30/34, 00-725 Warsaw, Poland

2 Eumedica S.A., Chemin de Nauwelette 1, 7170 Manage, Belgium classical and extended-spectrum TEM, SHV, and CTX-M enzymes and AmpC $\beta$-lactamases. Temocillin is used in few Western Europe countries [3], and only limited data are available on temocillin susceptibility in Eastern Europe, where microbial resistance to many antimicrobials is prevalent. According to the most recent report from the European Centre for Disease Prevention and Control in Poland over $65 \%$ of Klebsiella pneumoniae isolates reported to the European Antimicrobial Resistance Surveillance Network (EARS-Net) in 2018 were resistant to extended-spectrum cephalosporins; this represents an increase compared to previous years [4].

The aim of the present study was to evaluate the in vitro activity of temocillin and compare it to the activities of commonly used antimicrobials in respect of a large collection of Enterobacterales bacteria, especially ESBL- and/or AmpCproducing strains isolated from Polish patients with various infections. 


\section{Materials and methods}

The non-duplicate, well-characterized, clinical Enterobacterales isolates used in the present study were collected during laboratory surveillance conducted by the National Reference Centre for Susceptibility Testing between January 2000 and 2017 (Table 1). All the isolates were subcultured from storage $\left(\right.$ at $-70{ }^{\circ} \mathrm{C}$ ) and reidentified prior to testing. ESBL production and AmpC expression were verified using a double-disk synergy test, as previously described [5]. Klebsiella pneumoniae carbapenemase (KPC) production was verified using the disk test combined with phenylboronic acid [6] followed by polymerase chain reaction (PCR) [7]. $\beta$ lactamase production was controlled by PCR using specific primers for $b l a_{\mathrm{CTX}_{\mathrm{M}-1^{-}}}, b l a_{\mathrm{SHV}^{-}}, b l a_{\mathrm{TEM}^{-}}$, and $b l a_{\mathrm{KPC}^{-}}-$like genes [8]. The $b l a_{\mathrm{KPC}}$ gene amplicons were all digested using a restriction enzyme (RsaI; Thermo Scientific, Vilnius, Lithuania), which allowed $b l a_{\mathrm{KPC}-2^{-}}$and $b l a_{\mathrm{KPC}-3^{-}}$like variants to be distinguished [9].

The minimal inhibitory concentrations (MICs) of temocillin and 16 other antibiotics listed in Table 2 were evaluated using the microdilution method according to standard ISO 20776-1. The MIC of ceftazidime/avibactam was determined only for KPC-producing strains using a MIC Test Strip (Liofilchem $®$, Roseto degli Abruzzi, Italy). The quality control strains used in the study were: Escherichia coli ATCC 25922, Pseudomonas aeruginosa ATCC 27853, and Escherichia coli mcr-1-producing strain. The data were interpreted using EUCAST guidelines, except for temocillin and cefoxitin, where BSAC and CLSI breakpoints were used, respectively [10-12].

\section{Results}

The 400 isolates tested were recovered from urine (35\%), blood $(13 \%)$, and other clinical specimens (52\%; from bronchial secretions, cerebrospinal fluid, peritoneal fluid, pleural fluid, pus, skin lesions, sputum, and wounds) (Table 1). With regard to the resistant phenotypes, isolates producing ESBLs (CTX-M, SHV, or TEM) and/or isolates with acquired or overexpressed AmpC-type $\beta$-lactamase were the most prevalent $(n=260,65 \%)$, followed by KPC-producing isolates $(n=$ $40,10 \%)$, mostly represented by KPC-like-3-positive bacteria $(n=24,60 \%)$ (Table 1).

Table 1 Characterisation of the Enterobacterales strains tested

\begin{tabular}{|c|c|c|c|c|c|c|}
\hline Variable & $\begin{array}{l}\text { Klebsiella spp. }{ }^{1} \\
(n=196)\end{array}$ & $\begin{array}{l}\text { Escherichia coli } \\
(n=81)\end{array}$ & $\begin{array}{l}\text { Proteus spp. } \\
(n=38)\end{array}$ & $\begin{array}{l}\mathrm{CESP}^{3} \\
(n=83)\end{array}$ & $\begin{array}{l}\text { Other species }{ }^{4} \\
(n=2)\end{array}$ & $\begin{array}{l}\text { Total } \\
(n=400)\end{array}$ \\
\hline non-ESBL/AmpC/KPC & 38 & 38 & 8 & 16 & 0 & 100 \\
\hline AmpC & 1 & 1 & 18 & 19 & 0 & 39 \\
\hline ESBL & 88 & 40 & 8 & 39 & 2 & 177 \\
\hline CTX-M & 71 & 31 & 7 & 31 & 2 & 142 \\
\hline SHV & 9 & 4 & 1 & 6 & 0 & 20 \\
\hline CTX-M + SHV & 8 & 0 & 0 & 1 & 0 & 9 \\
\hline TEM & 0 & 3 & 0 & 1 & 0 & 4 \\
\hline CTX-M + TEM & 0 & 2 & 0 & 0 & 0 & 2 \\
\hline ESBL/AmpC & 34 & 0 & 4 & 6 & 0 & 44 \\
\hline CTX-M & 27 & 0 & 4 & 6 & 0 & 37 \\
\hline CTX-M + SHV & 7 & 0 & 0 & 0 & 0 & 7 \\
\hline $\mathrm{KPC}$ & 35 & 2 & 0 & 3 & 0 & 40 \\
\hline KPC-2-like & 11 & 2 & 0 & 3 & 0 & 16 \\
\hline KPC-3-like & 24 & 0 & 0 & 0 & 0 & 24 \\
\hline urine & 72 & 30 & 16 & 21 & 1 & 140 \\
\hline blood & 33 & 8 & 3 & 8 & 0 & 52 \\
\hline other $^{5}$ & 91 & 43 & 19 & 54 & 1 & 208 \\
\hline
\end{tabular}

${ }^{1}$ Klebsiella pneumoniae (186 isolates); Klebsiella oxytoca (10 isolates)

${ }^{2}$ Proteus mirabilis (36 isolates); Proteus penneri (1 isolate); Proteus vulgaris (1 isolate)

${ }^{3}$ CESP: Citrobacter spp. (C. freundii (18 isolates), C. braakii (2 isolates)); Enterobacter spp. (E. cloacae (34 isolates), E. aerogenes (2 isolates), E. amnigenus (1 isolate)); Serratia spp. (S. marcescens (18 isolates)); Morganella spp. (M. morganii (5 isolates)); and Providencia spp. (P. rettgeri (3 isolates))

${ }^{4}$ Kluyvera intermedia (1 isolate); Aeromonas sobria (1 isolate)

${ }^{5}$ bronchial secretions; cerebrospinal fluid; peritoneal fluid; pleural fluid; pus; skin lesions; sputum; wounds 


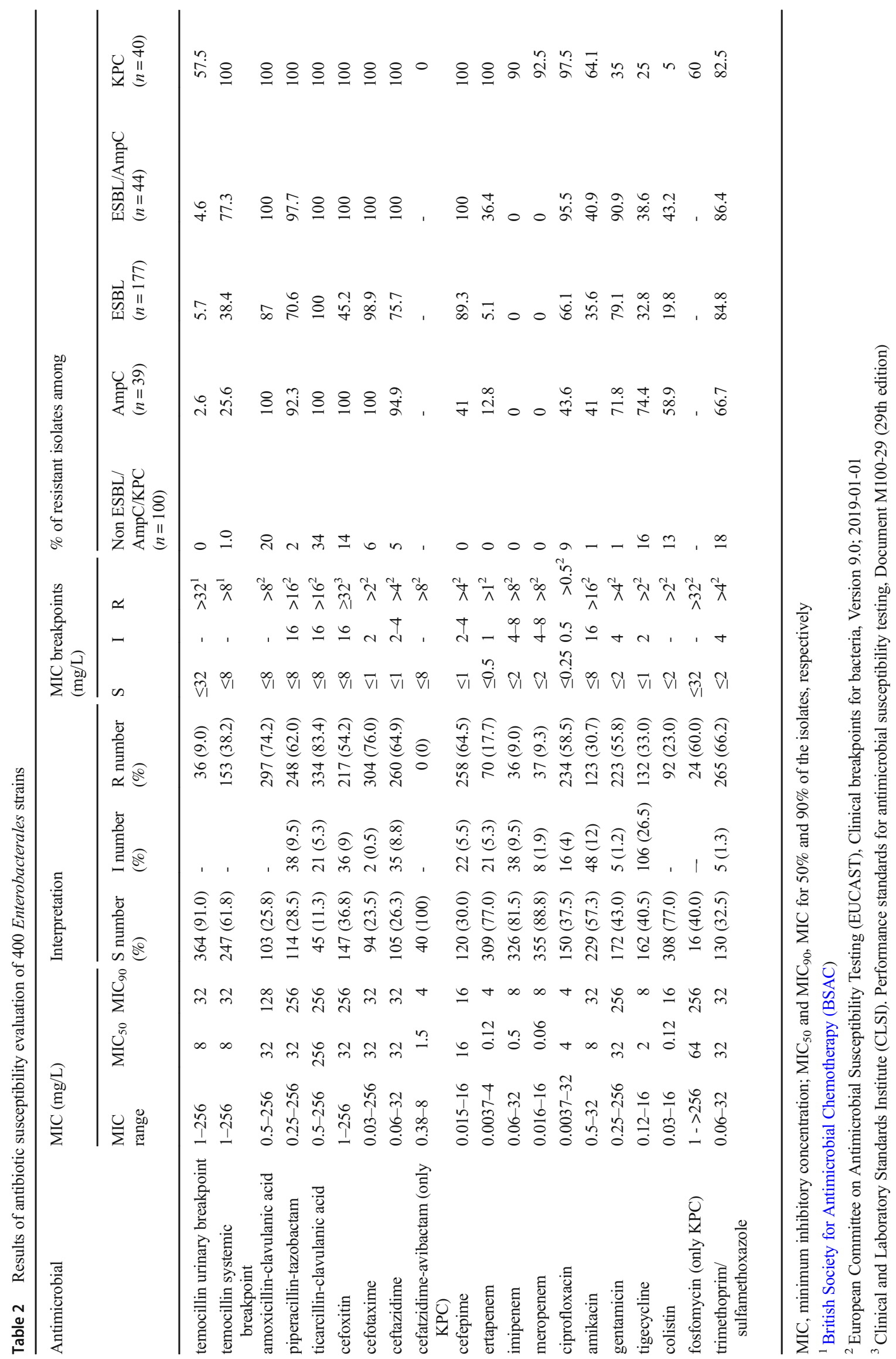


The results of a detailed analysis of the susceptibility data are shown in Table 2. The MICs of temocillin ranged from 1 to $256 \mathrm{mg} / \mathrm{L}$. Most of the isolates $(n=364,91 \%)$ had an MIC value between 4 and $32 \mathrm{mg} / \mathrm{L}\left(\mathrm{MIC}_{50}\right.$ and $\mathrm{MIC}_{90}$ values of 8 and $32 \mathrm{mg} / \mathrm{L}$, respectively) (Table 2). Overall, $91 \%$ of the isolates were susceptible to temocillin according to the BSAC urinary breakpoint $(\leq 32 \mathrm{mg} / \mathrm{L})$, and $61.7 \%$ were susceptible according to the systemic breakpoint. Temocillin was very effective against all the species tested when the urinary breakpoint was used (Table 3). According to the systemic breakpoint, temocillin was less effective against Klebsiella and CESP spp. (Citrobacter, Enterobacter, Serratia, Providencia, Morganella, and Hafnia that produced inducible chromosomally encoded AmpC-type) with resistance values of $53.1 \%$ and $44.6 \%$, respectively. Among the CESP members, the most resistant species were Serratia marcescens (88.9\%) and Enterobacter spp. (35.1\%) (data not shown).

According to the urinary breakpoint, among the ESBLand/or AmpC-producing isolates, the temocillin susceptibility rates were between $94 \%$ and $97 \%$. According to the systemic breakpoint, the susceptibility rates were $22.7 \%$ for ESBL- and AmpC-producers, $61.6 \%$ for ESBL-producers, and $74.4 \%$ for AmpC-producers (Table 2).

The KPC producers were resistant to several antimicrobials. These isolates were all resistant to temocillin according to the systemic infection breakpoint, but only $42.5 \%$ were susceptible according to the urinary tract infection breakpoint. Ceftazidime/avibactam (100\% susceptibility) and colistin (95\% susceptibility) were the most effective against KPCproducing isolates.

\section{Discussion}

Temocillin has been used for several years in some European countries, and is approved for the treatment of septicaemia, and urinary tract and lower respiratory tract infections [13-16]. However, it is still not available in Poland. Therefore, in the present analysis we assessed the prevalence of susceptibility to temocillin in Enterobacterales bacteria before it becomes available in our country.

There are currently no EUCAST breakpoints for temocillin [10]. Therefore, Enterobacterales bacteria are categorized as susceptible at MIC values of 8,16 , or $32 \mathrm{mg} / \mathrm{L}$, depending on the country [14]. In the present study, we used BSAC [11] clinical breakpoints with criteria established separately for systemic $(8 \mathrm{mg} / \mathrm{L})$ and urinary tract $(32 \mathrm{mg} / \mathrm{L})$ infections. The temocillin $\mathrm{MIC}_{50}$ and $\mathrm{MIC}_{90}$ values for the total set of isolates calculated according to the urinary breakpoint were higher than those reported by Alexandre et al. [14] for urinary tract infection (UTI) isolates ( 8 and $32 \mathrm{mg} / \mathrm{L}$ versus 3 and $6 \mathrm{mg} / \mathrm{L}$, respectively). However, our set of isolates comprised both UTI cases and isolates from other sites of infection.
When MICs were calculated only for isolates from urine, the $\mathrm{MIC}_{50}$ and $\mathrm{MIC}_{90}$ values were similar (data not shown), suggesting a possible role for temocillin in the treatment of urinary tract infections in Poland, regardless of the clinical breakpoint used. As expected, based on the literature nonESBL/AmpC/KPC-producing isolates were very susceptible $(100 \%$ and $99 \%)$, regardless of the clinical breakpoint used [15-18].

With regard to bacterial species tested and according to the urinary breakpoint, temocillin retained a high level of activity against all bacterial species producing ESBL and/or AmpC enzymes. However, when the systemic infection breakpoint was applied, only E. coli and Proteus spp. species remained susceptible, suggesting a possible role for temocillin in the treatment of urinary tract infections due to those two species [19]. More generally, temocillin was highly effective against most Enterobacterales bacteria, especially when the urinary tract infection breakpoint was used, and was least active against $K$. pneumoniae. The second most temocillin-resistant species was $S$. marcescens, with $77.8 \%$ of resistant isolates harbouring CTX-M enzymes (data not shown).

The majority of ESBL- or ESBL/AmpC-producers were susceptible using the urinary breakpoint but the resistance rate increased significantly using the systemic breakpoint. Previously, Rodriguez-Villalobos et al. [18] and Kresken et al. [20] pointed out that CTX-M-15 producers were less frequently susceptible to temocillin than other CTX-M-typeproducing isolates. In Poland, as in other European countries, the population of Enterobacterales bacteria has been dominated by CTX-M-15 producers [21].

With regard to $K$. pneumoniae, the temocillin-resistant strains were dominated by CTX-M- and KPC-producing isolates, regardless of the sample origin (data not shown). Contrary to the previous reports by Adams-Haduch et al. [22] and Woodford et al. [23], we were unable to confirm the susceptibility to temocillin among KPC-producing isolates. In the present study, $100 \%$ and over $50 \%$ of the KPCproducers were resistant to temocillin according to the systemic and urinary breakpoints, respectively. Our data are however in line with a report from Greece describing low temocillin activity against KPC-producers: $97.3 \%$ and $42 \%$ were resistant according to systemic and urinary breakpoints, respectively [24]. The low number of KPC-producing isolates is a limitation of the study, but the set of clinical isolates tested was representative of the population of KPC-producing isolates cultured from clinical specimens between 2010 and 2017 in Poland. However, among our KPC-producers, $20 \%$ had CTX$\mathrm{M}$ enzymes and this could already be a reason why they are more resistant to temocillin. It would be of interest to further investigate the presence of other resistance mechanisms such as upregulated efflux or permeability for instance.

The present study is the first Polish evaluation of the in vitro susceptibility of Enterobacterales isolates to 


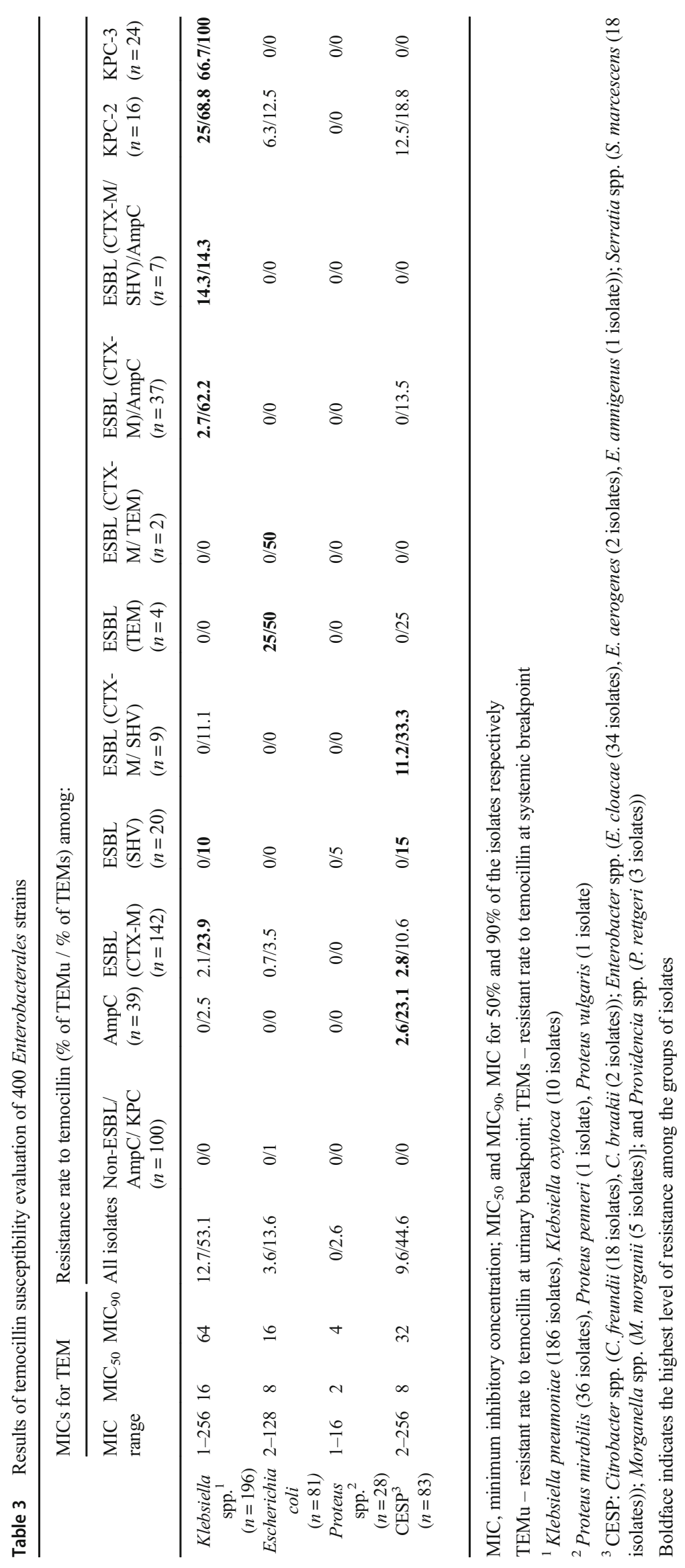


temocillin. It demonstrated the effectiveness of the antibiotic against a collection of tested microbes, especially when the urinary breakpoint was used. In contrast with previously published data, our study did not confirm the susceptibility of KPC-producing isolates to temocillin.

Acknowledgements We are very grateful to Marek Gniadkowski for his helpful advice, and to Anna Baraniak for her excellent technical expertise and assistance.

This study was supported in part by a grant from Eumedica S.A., Brussels, Belgium. Some of the data included in this manuscript were presented at the 28th European Congress of Clinical Microbiology and Infection Diseases (Madrid, 2018).

Author contributions statement This study was designed by WH, AK, and SVDV. The experimental work was carried out by BZ, AK, EL, and DZ. The data were analysed and interpreted by AK, WH, DZ, and AS. The manuscript was drafted and written by $\mathrm{AK}, \mathrm{BZ}$, and $\mathrm{WH}$; revised by SVDV, DZ, EL, and AS; and finally reviewed by all the authors.

\section{Compliance with ethical standards}

Conflict of interest SVDV is an employee of Eumedica S.A.; WH and AK have received sponsorship from Eumedica S.A. to attend scientific meetings; BZ, DŻ, EL, and AS declare that they have no competing interests.

Open Access This article is licensed under a Creative Commons Attribution 4.0 International License, which permits use, sharing, adaptation, distribution and reproduction in any medium or format, as long as you give appropriate credit to the original author(s) and the source, provide a link to the Creative Commons licence, and indicate if changes were made. The images or other third party material in this article are included in the article's Creative Commons licence, unless indicated otherwise in a credit line to the material. If material is not included in the article's Creative Commons licence and your intended use is not permitted by statutory regulation or exceeds the permitted use, you will need to obtain permission directly from the copyright holder. To view a copy of this licence, visit http://creativecommons.org/licenses/by/4.0/.

\section{References}

1. Pfeifer Y, Cullik A, Witte W (2010) Resistance to cephalosporins and carbapenems in gram-negative bacterial pathogens. Int J Med Microbiol 300:371-379

2. Livermore DM, Tulkens PM (2009) Temocillin revived. J Antimicrob Chemother 63:243-245

3. Habayeb H, Sajin B, Patel K, Grundy C, Al-Dujaili A, Van de Velde $\mathrm{S}$ (2015) Amoxicillin plus temocillin as an alternative empiric therapy for the treatment of severe hospital-acquired pneumonia: results from a retrospective audit. Eur J Clin Microbiol Infect Dis 34:16931699

4. European Centre for Disease Prevention and Control. Surveillance of antimicrobial resistance in Europe 2018. Stockholm: ECDC; 2019. Available from: https://www.ecdc.europa.eu/en/ publications-data/surveillance-antimicrobial-resistance-europe2018. Accessed 20 January 2020
5. Drieux L, Brossier F, Sougakoff W, Jarlier V (2008) Phenotypic detection of extended-spectrum beta-lactamase production in Enterobacteriaceae: review and bench guide. Clin Microbiol Infect 14:90-103

6. Doi Y, Potoski BA, Adams-Haduch JM, Sidjabat HE, Pasculle AW, Paterson DL (2008) Simple disk-based method for detection of Klebsiella pneumoniae carbapenemase-type beta-lactamase by use of a boronic acid compound. J Clin Microbiol 46:4083-4086

7. Navon-Venezia S, Chmelnitsky I, Leavitt A, Schwaber MJ, Schwartz D, Carmeli Y (2006) Plasmid-mediated imipenem-hydrolyzing enzyme KPC-2 among multiple carbapenem-resistant Escherichia coli clones in Israel. Antimicrob Agents Chemother 50:3098-3101

8. Empel J, Baraniak A, Literacka E, Mrówka A, Fiett J, Sadowy E, Hryniewicz W, Gniadkowski M, Beta-PL Study Group (2008) Molecular survey of beta-lactamases conferring resistance to newer beta-lactams in Enterobacteriaceae isolates from polish hospitals. Antimicrob Agents Chemother 52:2449-2454

9. Lopez JA, Correa A, Navon-Venezia S, Correa AL, Torres JA, Briceño DF, Montealegre MC, Quinn JP, Carmeli Y, Villegas MV (2011) Intercontinental spread from Israel to Colombia of a KPC-3producing Klebsiella pneumoniae strain. Clin Microbiol Infect 17: $52-56$

10. European Committee on Antimicrobial Susceptibility Testing (2019). Breakpoint tables for interpretation of MICs and zone diameters. Version 9.0, valid from 01-01-2019. http://www.eucast. org/fileadmin/src/media/PDFs/EUCAST_files/Breakpoint_tables/ v_9.0_Breakpoint_Tables.pdf. Accessed 06 November 2019

11. Andrews JM, Jevons G, Walker R, Ashby J, Fraise AP (2007) Temocillin susceptibility by BSAC methodology. J Antimicrob Chemother 60:185-187

12. Clinical and Laboratory Standards Institute (CLSI) (2019) CLSI document M100-29. Performance standards for antimicrobial susceptibility testing, 29th edn. CLSI, Wayne

13. Alexandre K, Fantin B (2018) Pharmacokinetics and pharmacodynamics of temocillin. Clin Pharmacokinet 57:287-296

14. Alexandre K, Réveillon-Istin M, Fabre R, Delbos V, Etienne M, Pestel-Caron M, Dahyot S, Caron F (2018) Temocillin against Enterobacteriaceae isolates from community-acquired urinary tract infections: low rate of resistance and good accuracy of routine susceptibility testing methods. J Antimicrob Chemother 73:18481853. https://doi.org/10.1093/jac/dky101

15. Livermore DM, Hope R, Fagan EJ, Warner M, Woodford N, Potz N (2006) Activity of temocillin against prevalent ESBL- and AmpCproducing Enterobacteriaceae from south-east England. J Antimicrob Chemother 57:1012-1014

16. Glupczynski Y, Huang TD, Berhin C, Claeys G, Delmée M, Ide L, Ieven G, Pierard D, Rodriguez-Villalobos H, Struelens M, Vaneldere J (2007) In vitro activity of temocillin against prevalent extended-spectrum beta-lactamases producing Enterobacteriaceae from Belgian intensive care units. Eur J Clin Microbiol Infect Dis 26:777-783

17. Mischnik A, Baumert P, Hamprecht A, Rohde A, Peter S, Feihl S, Knobloch J, Gölz H, Kola A, Obermann B, Querbach C, Willmann M, Gebhardt F, Tacconelli E, Gastmeier P, Seifert H, Kern WV, DZIF-ATHOS Study Group (2017) Susceptibility to penicillin derivatives among third-generation cephalosporin-resistant Enterobacteriaceae recovered on hospital admission. Diagn Microbiol Infect Dis 87:71-73

18. Rodriguez-Villalobos H, Malaviolle V, Frankard J, de Mendonça R, Nonhoff C, Struelens MJ (2006) In vitro activity of temocillin against extended spectrum beta-lactamase-producing Escherichia coli. J Antimicrob Chemother 57:771-774 
19. Zykov IN, Sundsfjord A, Småbrekke L, Samuelsen Ø (2016) The antimicrobial activity of mecillinam, nitrofurantoin, temocillin and fosfomycin and comparative analysis of resistance patterns in a nationwide collection of ESBL-producing Escherichia coli in Norway 2010-2011. Infect Dis (Lond) 48:99-107. https://doi.org/ 10.3109/23744235.2015.1087648

20. Kresken M, Körber-Irrgang B, Pfeifer Y, Werner G (2018) Activity of temocillin against CTX-M-producing Escherichia coli and Klebsiella pneumoniae from Germany. Int J Antimicrob Agents 51:159-160. https://doi.org/10.1016/j.ijantimicag.2017.06.014

21. Livermore DM, Canton R, Gniadkowski M, Nordmann P, Rossolini GM, Arlet G, Ayala J, Coque TM, Kern-Zdanowicz I, Luzzaro F, Poirel L, Woodford N (2007) CTX-M: changing the face of ESBLs in Europe. J Antimicrob Chemother 59:165-174. https://doi.org/10.1093/jac/dk1483

22. Adams-Haduch JM, Potoski BA, Sidjabat HE, Paterson DL, Doi Y (2009) Activity of temocillin against KPC-producing Klebsiella pneumoniae and Escherichia coli. Antimicrob Agents Chemother 53:2700-2701. https://doi.org/10.1128/AAC.00290-09
23. Woodford N, Pike R, Meunier D, Loy R, Hill R, Hopkins KL (2014) In vitro activity of temocillin against multidrug-resistant clinical isolates of Escherichia coli, Klebsiella spp. and Enterobacter spp., and evaluation of high-level temocillin resistance as a diagnostic marker for OXA-48 carbapenemase. J Antimicrob Chemother 69:564-567. https://doi.org/10.1093/jac/dkt383

24. Galani I, Karaiskos I, Karantani I, Papoutsaki V, Maraki S, Papaioannou V, Kazila P, Tsorlini H, Charalampaki N, Toutouza M, Vagiakou H, Pappas K, Kyratsa A, Kontopoulou K, Legga O, Petinaki E, Papadogeorgaki H, Chinou E, Souli M, Giamarellou H, On Behalf Of The Study Collaborators (2018) Epidemiology and resistance phenotypes of carbapenemase-producing Klebsiella pneumoniae in Greece, 2014 to 2016. Euro Surveill 23. https:// doi.org/10.2807/1560-7917.ES.2018.23.30.1700775

Publisher's note Springer Nature remains neutral with regard to jurisdictional claims in published maps and institutional affiliations. 